\title{
Fading Away the Borders Between Religion and Science: The Proposal from the Spiritist Medical Model
}

\author{
Marcelo Saad $^{1^{*}}$, Roberta de Medeiros ${ }^{2}$ and Amanda Cristina Fávero Mosini ${ }^{3}$ \\ ${ }^{1}$ Spiritist Medical Association of Brazil, São Paulo, Brazil \\ ${ }^{2}$ Centro Universitario São Camilo, São Paulo, Brazil \\ ${ }^{3}$ Universidade Federal de São Paulo, São Paulo, Brazil
}

*Corresponding author: Marcelo Saad, Medical-Spiritist Association of Brazil, Av. Pedro Severino 323, Jabaquara, São Paulo, Brazil, Tel: +55 11 2574-8696; E-mail: msaad@uol.com.br

Received date: September 11, 2017; Accepted date: September 27, 2017; Published date: September 30, 2017

Copyright: $\odot 2017$ Saad M, et al. This is an open-access article distributed under the terms of the Creative Commons Attribution License, which permits unrestricted use, distribution, and reproduction in any medium, provided the original author and source are credited.

\begin{abstract}
There is a common notion that science and religion are in conflict and have little in common. However, authorities from both sides timidly rehearse an approach intention. Some phenomena that seem to counteract the common sense of reality are genuine calls for collaboration between science and religion. Spiritism (not synonym of spiritualism) was conceived as science, philosophy, and religion, all together. The form into which Spiritism has evolved in Brazil is very peculiar, taking contours of a religious denomination. Specific therapeutic approaches were developed to prevent and to restore a balanced spiritual-energetic state. Thus, most adepts search spiritist centres due to physical and mental health problems. The interest on the interface between medicine and the Spiritist Doctrine led to the creation of the Spiritist Medical Association. The Spiritist Medical Model aims at a change to a more humanized medicine, with a pretension of presenting to the world a renewed vision of the human being. Thus, it also brought the philosophical dictates from Spiritism to value implications of healthcare practices. Spiritism has many arguments with potential do fill some gaps about the human nature, which can contribute to understanding many unexplained or misinterpreted phenomena. Medical debates may be enriched with its principles, with potential to contribute for a paradigm shift on medicine and science. Currently, scholar researchers linked to this ideal are trying to sew all these fields in a continuous fabric. Who knows if, in the next 50 years, this constant dialog among science, philosophy, religion, medicine and bioethics will fade off the borders of these disciplines? At this point, the human knowledge will be facing a real paradigm shift.
\end{abstract}

Keywords: Bioethical issue; Medicine and religion; Religion and science; Humanities; Medical philosophy; Spiritism; Metaphysical mind body relation

\section{Introduction}

\section{Religion and science}

"Acceptance without proof is the fundamental characteristic of Western religion; rejection without proof is the fundamental characteristic of Western science" (quote attributed to Gary Zukav, North-American writer). This phrase may be generalizer and disproportionate, but it highlights the common notion that science and religion are in conflict and have little in common. However, for most of human history, religion and science were closely linked. In ancient times, for instance, the study of the sky and the stars extracted information for many readings, both concrete (best season to plant or guidance for navigation) and for abstract (the mood of deities or the destiny of people). The last centuries had several movements of distancing and approaching between science and religion. Today, authorities from both sides timidly rehearse an approach intention. Many religious leaders see opportunities of compatibility, mutuality and complementarity related to the science-faith relationship [1]. At the same time, some scholars and researchers anticipate the need for a transition to a new scientific paradigm that includes non-material elements of consciousness [2].
Some phenomena that seem to counteract the common sense of reality are genuine calls for collaboration between science and religion. Since late XIX century, renowned scientists from Europe and United States became interested in anomalous phenomena of consciousness [3]. The psychic research societies aimed at the application of scientific methodology to study such matter. Despite strong opposition from the academic thinking and the great difficulty in publishing results, some research went on throughout the XX century. Recently, many studies with correct methodology have documented disconcerting phenomena. Some examples include miraculous cures, anomalous reception of information, memories of supposed past lives, and neardeath experiences [4]. Many ancient practices, religious traditions, and contemplative approaches have their conceptions to explain how consciousness may be independent of brain activity. Among them, perhaps the most structured one is Spiritism.

\section{The spiritism fundamentals}

Spiritism was codified by the French teacher and educator Hippolyte L. D. Rivail (1804-1869), also known by his pseudonym Allan Kardec. By the mid-1800's, he made a rational investigation of communication with spirits. He defined Spiritism as "a science which deals with the nature, origin and destiny of spirits, as well as their relationship with the material world". He compiled the answers provided from the spirits for questions regarding the origin of the spirits, the purpose of the life, the order of the universe, evil and good and the afterlife. Spiritism is considered science, philosophy, and religion, all together. The science 
studies the existence and nature of spirits; the philosophy describes the role we play in our own spiritual evolution; and the religious aspect puts Jesus as the greatest moral example for humankind.

Spiritism is not synonym of "spiritualism", but a particular interpretation of many spiritualist concepts. The central tenet of Spiritism is the belief in spiritual life, constructed with some specificities. The successive reincarnations in the material world are opportunities to learn and to develop potentials, to approach perfection. The guide for this progress, the teaching of the spirits, came to complement the gospels. Communication between spirits and the living people are possible to varying degrees. Spirits can exert actions upon men's thought, in either constructive or destructive ways. In more sensitive people, this influence may lead to states of health or disease, both physical and/or mental. Specific therapeutic approaches were developed to prevent and to restore a balanced spiritual-energetic state, counting on the help of benefactor spirits.

Spiritism has spread to many countries, and Brazil is the country it flourished most, and it is the country where the most significant number of followers can be found. The form into which Spiritism has evolved in Brazil is very peculiar. While essentially Spiritism emerged essentially as a philosophical movement, it took contours of a religious denomination in Brazil. Currently, Spiritism is the religion declared by $2 \%$ of the Brazilian population, according to the last national census [5]. Spiritism is manifested in various activities in the spiritist centres. However, most goers search Spiritism due to physical and mental health problems [6]. Thus, spiritist centres are an important supplementary health support system, since they offer a range of therapeutic resources intended to restore health.

\section{The spiritist medical model}

Almost half century ago, on 1968, a group of physicians interested on the interface between medicine and the Spiritist Doctrine created in S. Paulo city (Brazil) the first Spiritist Medical Association (SMA). This initiative inspired, over the years, the creation of other regional SMAs all over the country. In 1995, the SMA-Brazil was created with the purpose of aggregating all existing SMAs. Later, this ideal overcame international borders. The SMA-International, idealized in Brazil, currently counts with representative associations in the Americas and Europe: Argentina, Colombia, Cuba, France Guatemala, Portugal, Switzerland, and United States. The Spiritist Medical Model of health and treatment, developed along these decades, refers to the set of Spiritist dictates that can contribute to a paradigm shift in Health Sciences.

Spiritism provides some insights to many of modern clusters of topics that fall within the domain of bioethics. The Spiritist Medical Model aims at a change to a more humanized Medicine, with a pretension of presenting to the world a renewed vision of the human being. Thus, the SMA-Brazil also brought the philosophical dictates from Spiritism to value implications of healthcare practices. For great bioethical issues, such as abortion and euthanasia, the Spiritist Medical Model has very strong positions. Other widely discussed bioethical issues, under the light of Spiritist dictates, include birth control methods, use of embryonic stem cells for research, and human cloning initiatives. End-of-life issues are also contemplated, such as will directives, organs donation, necropsy, and cremation.

Some bioethical actions from the SMAs are focally done, according to the presented situation. In 2015, the Ministry of Health detected an unusual increase in the number of cases of microcephaly. A Committee of the World Health Organization concluded on a strongly suspected causal relationship between such outbreak and the Zika virus infection during pregnancy [7]. Based on these findings, some groups proposed a lawsuit by abortion rights in pregnancies of babies with microcephaly. All SMAs reiterated the institutional position against abortion. In 2016, the SMA-Brazil, with a technical report, collaborated on the Federal Supreme Court decision to prohibit the practice of a kind of bullfighting, which involved mistreatment and cruelty to animals.

\section{Towards a true science-religion continuity}

Spiritism has many arguments with potential do fill some gaps about the human nature, which can contribute to understanding many unexplained or misinterpreted phenomena. Medical debates may be enriched with principles such as the relation of spiritual body with health, reincarnation as a cause of some diseases, communication with spirits as cause of some disturbances, and healing through spiritual energies. Many Spiritist dictates have potential to contribute for a paradigm shift on medicine and science [8]. However, such big change must be managed in small but effective steps. All the SMAs develop continuously many actions to study these principles, aiming the clinical application of findings. Some members of SMA-Brazil published their research on reputable peer-reviewed medical journals.

Some contemporary examples of this productivity is listed as follows, in chronological order: guidelines to differentiate genuine spiritual experiences from psychotic dissociative disorders [9]; evidence by neuroimaging that mediumistic psychography trance is different from writing a mere essay [10]; argumentation for psychotherapeutic approaches take into account the patient's belief in reincarnation, when present [11]; study about the fit and accuracy of information received through mediumship [12]; a report of knowledge by a medium about melatonin functions, many years before it was described [13]; a tentative conciliation between distant healing techniques (including intercessory prayer) and science [14]; a bibliometric review about experiences pointing to autonomy of consciousness in relation to brain [15]; and an open-mind report and discussion about end-of-life experiences and deathbed phenomena [16].

\section{Conclusion}

About 150 years ago, on its creation at France, Spiritism was conceived as a scientific, philosophical and religious doctrine. At that time, in Europe, the scientific aspect prevailed, supporting research of some psychic phenomena. More than 100 years ago, in Brazil, the religious dimension prevailed, alongside with practices for health purposes. About 50 years ago, the Spiritist Medical movement structured the possible interface between Medicine and Spiritism. Currently, scholar researchers linked to this ideal are trying to sew all these fields in a continuous fabric. Who knows if, in the next 50 years, this constant dialog among science, philosophy, religion, medicine and bioethics will fade away the borders of these disciplines? At this point, the human knowledge will be facing a real paradigm shift.

\section{Conflict of Interest}

The first author (M.S.) is the current president of Spiritist Medical Association of S. Paulo (Brazil), although he has no financial gain from this position. Other authors declare there are not any actual or potential conflicts of interest. 
Citation: Saad M, de Medeiros R, Mosini ACF (2017) Fading Away the Borders Between Religion and Science: The Proposal from the Spiritist Medical Model. J Clin Res Bioeth 8: 313. doi:10.4172/2155-9627.1000313

Page 3 of 3

\section{Acknowledgement}

Authors are grateful to the Spiritist Medical Association of S. Paulo (Brazil) for the encouragement and support to the accomplishment of this manuscript.

\section{References}

1. Pritchard K (2016) Religion and science can have a true dialogue. Nature 537: 451.

2. Beauregard M, Schwartz GE, Miller L, Dossey L, Moreira-Almeida A, et al. (2014) Manifesto for a post-materialist science. Explore (NY) 10: 272-274.

3. Lachapelle S (2005) Attempting science: the creation and early development of the Institut métapsychique international in Paris, 1919-1931. J Hist Behav Sci 41: 1-24.

4. Bonilla E (2010) Mind-body connection, parapsychological phenomena and spiritual healing - a review. Invest Clin 51: 209-238.

5. IBGE - Instituto Brasileiro de Geografia e Estatística. Censo Demográfico 2010 - Características gerais da população, religião e pessoas com deficiência.

6. Lucchetti AL, Lucchetti G, Leão FC, Peres MF, Vallada H (2016) Mental and Physical Health and Spiritual Healing: An Evaluation of Complementary Religious Therapies Provided by Spiritist Centers in the City of São Paulo, Brazil. Cult Med Psychiatry 40: 404-421.

7. World Health Organization (2016) Zika Situation Report - Neurological Syndrome And Congenital Anomalies.

8. Saad M, de Medeiros R (2017) Potential Contribution of the MedicalSpiritist Model to a New Paradigm on Medicine. Int J Complement Alt Med 8: 00262.
9. Moreira-Almeida A (2009) Differentiating spiritual from psychotic experiences. Br J Psychiatry 195: 370-371.

10. Peres JF, Moreira-Almeida A, Caixeta L, Leao F, Newberg A (2012) Neuroimaging during trance state: a contribution to the study of dissociation. PLoS One 7: e49360.

11. Peres JF (2012) Should psychotherapy consider reincarnation? J Nerv Ment Dis 200: 174-179.

12. Rocha AC, Paraná D, Freire ES, Lotufo Neto F, Moreira-Almeida A (2014) Investigating the fit and accuracy of alleged mediumistic writing: a case study of Chico Xavier's letters. Explore (NY) 10: 300-308.

13. Lucchetti G, Daher JC Jr, Iandoli D Jr, Gonçalves JP, Lucchetti AL (2013) Historical and cultural aspects of the pineal gland: comparison between the theories provided by Spiritism in the 1940s and the current scientific evidence. Neuro Endocrinol Lett 34: 745-755.

14. Saad M, de Medeiros R (2015) Distant Healing Techniques and Distant Intercessory Prayer - A Tentative Scientific Conciliation. Complementary Therapies for the Body, Mind and Soul.

15. Daher JC Jr, Damiano RF, Lucchetti AL, Moreira-Almeida A, Padlocks G (2017) Research on Experiences Related to the Possibility of Consciousness Beyond the Brain: A Bibliometric Analysis of Global Scientific Output. J Nerv Ment Dis 205: 37-47.

16. Santos CSD, Paiva BSR, Lucchetti ALG, Paiva CE, Fenwick P, et al. (2017) End-of-life experiences and deathbed phenomena as reported by Brazilian healthcare professionals in different healthcare settings. Palliat Support Care 15: 425-433. 